Volume 1 Issue 1, January-June 2020: pp.13-26.

Faculty of Law, Universitas Lampung, Bandar Lampung, Indonesia. http://jurnal.fh.unila.ac.id/index.php/ip

P-ISSN: 2723-2638

E-ISSN: $2745-9314$

\title{
Penilaian Hakim Terhadap Keterangan Saksi Korban Penyandang Retardasi Mental dalam Perkara Perkosaan
}

\author{
Judge's Assessment of the Statement of a Witness Victim with Mental \\ Retardation in a Rape Case
}

\author{
Astri Wijayanti \\ astriwijayanti13@gmail.com \\ Kejaksaan Negeri Lampung Tengah
}

Submitted: Mar 16, 2020; Reviewed: Mar 31, 2020; Accepted: Apr 20, 2020

\section{Info Artikel}

Kata Kunci: Penilaian Hakim; Saksi; Retardasi Mental.

Keywords: Judge Rating; Witnesses; Mental Retardation.

DOI:

https://doi.org/10.25041/ip.v1i1.2060

\section{Abstrak}

Keterangan saksi korban dalam persidangan mempunyai peranan penting dalam pembuktian suatu perkara, dalam hal ini Hakim menggunakan keterangan saksi penyandang disabilitas retardasi mental sebagai alat bukti keterangan saksi. Permasalahanan dalam penulisan Jurnal ini adalah Bagaimanakah penilaian hakim terhadap keterangan saksi korban penyandang retardasi mental dalam perkara perkosaan? dan Apakah prinsip yang harus diperhatikan oleh hakim dalam penilaian keterangan saksi penyandang retardasi mental? Penelitian ini menggunakan pendekatan secara yuridis empiris dan yuridis normatif. Hasil penelitian menunjukan bahwa Penilaian hakim terhadap keterangan saksi penyandang retardasi mental dalam perkara pidana pada dasarnya tidak terikat. Hakim dapat mempergunakannya keterangan saksi penyandang retardasi mental sebagai alat bukti keterangan saksi dengan mempertimbangkan hasil penelitian dari ahli kejiwaan yang bisa dipertanggungjawabkan lus Poenale is a journal published by Faculty of Law, Universitas Lampung, under a Creative Commons Attribution-ShareAlike 4.0 International License. 
secara akademis untuk membantu saksi penyandang retardasi mental agar dapat memberikan keterangan yang tentu saja bisa dipastikan kebenarannya, hakim juga dapat mempergunakannya sebagai tambahan pembuktian maupun sebagai alat bukti petunjuk apabila terdapat persesuaian dengan alat bukti lain yang sah. Prinsip yang harus diperhatikan oleh hakim dalam penilaian keterangan saksi penyandang retardasi mental dilakukan dengan berdasarkan pada prinsipprinsip pengadilan yang fair yaitu: persamaan kedudukan di depan hukum, persidangan terbuka untuk umum dan dilakukan secara lisan, pengadilan yang kompeten, independen dan tidak memihak. Saran yang disampaikan penulis dalam penelitian ini. Hakim harus bersikap bijak dalam menggunakan alat bukti yang ada terutama dalam perkara yang sulit pembuktiannya.

\section{Abstract}

Victim witness testimony in a trial has an important role in proving a case, in this case the judge uses the testimony of a witness with a mental retardation as evidence for witness testimony. Issues in writing this Journal are How is the judge's assessment of the witness testimony of victims of mental retardation in rape cases? and What principle should be considered by judges in evaluating the testimony of witnesses with mental retardation? This research uses an empirical and normative juridical approach. The results showed that the Judge's evaluation of the testimony of witnesses with mental retardation in a criminal case was essentially independent. Judges can use the testimony of witnesses with mental retardation as evidence of witness testimony by considering the results of research from psychiatric experts who can be academically accounted for to help witnesses with mental retardation to be able to provide information which of course can be verified, the judge can also use it as additional proof or as evidence of instructions if there is compatibility with other valid evidence. The principle that must be considered by judges in evaluating the testimony of witnesses with mental retardation is based on the principles 
of a fair trial, namely: equality before the law, trials open to the public and conducted orally, competent, independent and impartial courts. Suggestions conveyed by the author in this study Judges must be wise in using existing evidence, especially in cases that are difficult to prove.

\section{A. Pendahuluan}

Hukum adalah pencerminan dari Hak Asasi Manusia, sehingga hukum mengandung keadilan atau tidak akan ditentukan oleh Hak Asasi Manusia yang terkandung dan juga diatur atau dijamin dalam hukum tersebut. Hukum tidak akan dipandang sebagai cerminan dari kekuasaan semata-mata, namun juga harus mencerminkan perlindungan terhadap hak-hak para warga negara. ${ }^{1}$ Saksi korban penyandang retardasi mental dalam perkara perkosaan ini juga harus mendapatkan perlindungan sebagai cerminan Hak Asasi Manusianya. Saksi dan/atau korban memiliki peran penting dalam penyelesaian permasalahan hukum khususnya dalam proses peradilan di Indonesia. Saksi dan/atau korban adalah mereka yang mendengar, melihat, atau mengalami sendiri terjadinya suatu tindak pidana sehingga keterangan mereka sangat dibutuhkan dalam upaya mencari dan menemukan kejelasan tentang tindak pidana yang dilakukan oleh pelaku tindak pidana. ${ }^{2}$ Mengingat kesaksian adalah salah satu instrumen penting dalam mengungkap suatu kebenaran, untuk memperoleh suatu informasi dibutuhkan faktorfaktor pendukung misalnya suatu keadaan yang menerangkan suatu peristiwa tersebut terjadi yang dapat diperoleh dari keterangan-ketetrangan yang berbentuk tertulis maupun lisan agar dicapainya suatu data yang akurat. Berkenaan dengan sistem pembuktian di negara Indonesia hukum positif sudah mengatur dengan jelas dan tertuang di dalam Kitab Undang-Undang Hukum Acara Pidana (KUHAP).Mengkaji dari perspektif sistem peradilan pada umumnya dan hukum acara pidana (formeel strafrecht/ strafprocesrecht) pada dasarnya aspek "pembuktian" memegang peranan dalam menentukan suatu kesalahan seseorang sehingga dapat dijatuhkan pidana oleh hakim. Jika kita lihat secara yuridis, aspek "pembuktian" terbilang unik karena dapat diklasifikasikan, baik dalam kelompok hukum acara pidana/hukum pidana formal maupun hukum pidana materiil. ${ }^{3}$ Proses pembuktian hakikatnya memang lebih dominan pada sidang pengadilan guna menemukan kebenaran materiil akan peristiwa yang terjadi dan memberi keyakinan kepada hakim tentang kejadian tersebut sehingga hakim dapat memberikan putusan yang adil. ${ }^{4}$ Pandangan terkait "pembuktian" dikategorisasikan ke dalam hukum pidana materiil oleh karena dipengaruhi adanya pendekatan dari hukum perdata dimana aspek "pembuktian" masuk dalam katagori hukum perdata materiil dan hukum perdata formal (hukum acara perdata). Akan tetapi, sejak berlakunya Undang-Undang Nomor 8 Tahun 1981 tentang Kitab Undang-Undang Hukum Acara Pidana (KUHAP), aspek "pembuktian" telah diatur dalam ketentuan hukum pidana formal. Pembuktian dilakukan guna menentukan nasib seorang terdakwa serta guna mencari dan mendapatkan fakta-fakta terhadap suatu peristiwa tindak

\footnotetext{
${ }^{1}$ Eka Intan et al., "Begal Anak; Pemenuhan Hak Dan Lembaga Pembinaan Khusus Anak Kelas II A Bandar Lampung Fulfillment Of The Rights Of The Child In The Class Ii Special Child Coaching Institution In Bandar Lampung," Cepalo 2, no. 2 (September 12, 2018): 45-84, https://doi.org/10.25041/cepalo.v2no2.1764.

${ }^{2}$ ZulkarnainRidlwan,"accessedJuly7,2020,https://www.researchgate.net/publication/336371833_Sandaran_Moral_Negara_H ukum_Indonesia_di_Era_Disrupsi_Teknologi. Jurnal Konstitusi.

${ }^{3}$ Lilik Mulyadi Mengutip Mardjono Reksodipoetro, Hak Asasi Manusia Dalam Sistem Peradilan Pidana, Kumpulan Karangan Buku Ketiga, Jakarta: Pusat Pelayanan Keadilan dan Pengabdian Hukum Universitas Indonesia, (1994), hlm. 84-85

4 Putra Akbar Saleh, "Tinjauan Yuridis Terhadap Putusan Hakim Yang Mengabaikan Bukti Keterangan Saksi di Dalam Persidangan" Lex Et Societatis, vol. https://ejournal.unsrat.ac.id/index.php/lexetsocietatis/article/view/1313.
} 
pidana. ${ }^{5}$ Pembuktian adalah ketentuan-ketentuan yang berisi pedoman tentang cara-cara yang dibenarkan undang-undang untuk membuktikan kesalahan yang didakwakan kepada terdakwa. ${ }^{6}$ Pemenuhan dan pemberian hak atas rasa aman untuk melindungi saksi dan korban dalam sebuah kasus pidana menjadi kebutuhan yang penting agar proses hukum di pengadilan berjalan dengan optimal. ${ }^{7}$

Secara umum "pembuktian" berasal dari kata "bukti” yang berarti suatu hal (peristiwa dan sebagainya) yang cukup untuk memperlihatkan kebenaran suatu hal (peristiwa tersebut). Membuktikan sama dengan memberi (memperlihatkan) bukti, melakukan sesuatu sebagai kebenaran, melaksanakan, mendatangkan, menyaksikan, dan meyakinkan ${ }^{8}$, sedangkan jika dikaji dengan makna leksikon "pembuktian" adalah suatu proses, cara, perbuatan membuktikan usaha menunjukan benar atau salahnya terdakwa dalam sidang pengadilan. ${ }^{9}$ Sedangkan jika dikaji dari perspektif yuridis. menurut M. Yahya Harahap "pembuktian" adalah ketentuanketentuan yang berisi penggarisan dan pedoman tentang cara-cara yang dibenarkan undangundang membuktikan kesalahan yang didakwakan kepada terdakwa. ${ }^{10}$ Pembuktian kesalahan terdakwa sangat memegang peran penting, karena jika teknik pembuktian tidak dilaksanakan dengan baik oleh Penuntut Umum, Hakim dan Penasehat Hukum, terdakwa dapat bebas dari hukuman. ${ }^{11}$

Berbicara mengenai pembuktian tidak lepas mengenai alat bukti keterangan saksi yang merupakan alat bukti paling utama dalam perkara pidana, dikarenakan hampir semua pemeriksaan hukum acara pidana selalu mengacu pada keterangan saksi di persidangan. Dengan alat bukti keterangan saksi akan lebih mengungkap peristiwa yang sesungguhnya terjadi. Namun tidak semua keterangan saksi bisa menjadi alat bukti yang sah. Keterangan saksi yang mempunyai nilai pembuktian adalah keterangan saksi yang memenuhi syarat materiil yaitu seseorang yang mendengar sendiri, melihat sendiri dan mengalami sendiri tentang suatu tindak pidana. Hal ini sesuai dengan apa yang ada di persidangan hukum acara pidana saksi memegang peranan penting dalam upaya pembuktian kesalahan terdakwa di dalam sidang pengadilan selain dari keyakinan hakim. Saksi merupakan alat pembuktian yang paling utama dalam hukum pidana sesuai dengan pengertian saksi dalam Pasal 1 angka 26 Kitab UndangUndang Hukum Acara Pidana Nomor 8 Tahun 1981 (KUHAP) yang berbunyi sebagai berikut: Saksi adalah orang yang dapat memberikan keterangan guna kepentingan penyidikan, penuntutan dan peradilan tentang suatu perkara pidana yang ia dengar sendiri, ia lihat sendiri dan ia alami sendiri. ${ }^{12}$ Seseorang yang akan bersaksi memiliki kewajiban untuk mengucapkan sumpah terlebih dahulu agar keterangannya dianggap sah atau memenuhi syarat formil. Dalam hal ini kesaksian dari seorang saksi masih tidak dapat dijamin kebenarannya, mengingat adanya kesaksian-kesaksian dari saksi lain yang bisa jadi berlawan ataupun tidak ada persesuaian antara saksi satu dengan saksi yang lainnya dalam satu perkara di persidangan.

\footnotetext{
${ }^{5}$ Saktia "Implikasi Yuridis Perluasan Definisi Saksi Dan Keterangan Saksi Berdasarkan Putusan Mahkamah Konstitusi Nomor". Jurnal Verstek. accessed July 7, 2020, https://jurnal.uns.ac.id/verstek/article/view/38819/25697.

${ }^{6}$ Mohammad Nurul Huda, "Pentingnya Alat Bukti dalam Pembuktian Minim Saksi.” Jurnal Voice Justisia. Vol. 1 No.2 (2017). hlm.97.

${ }^{7}$ Clasina Mutiara Juwita Panjaitan, and Ariyani Putri, "Peran Dari Lembaga Perlindungan Saksi Dan Korban (Lpsk) Dalam Pemerkosaan," Jurnal Hukum Pidana Dan Penanggulangan Kejahatan, vol. 2, April 1, 2013, https://jurnal.uns.ac.id/recidive/article/view/32018.

${ }^{8}$ Soedirjo, Jaksa Dan Hakim Dalam Proses Pidana, Jakarta: Akademikia Pressindo, (1985), Hlm. 47

${ }^{9}$ Pusat Bahasa Departemen Pendidikan Nasional, Kamus Besar Bahasa Indonesia, Balai Pustaka, Edisi Ketiga, Cetakan Keempat, (2005), Hlm. 172

${ }^{10}$ M. Yahya Harahap, Pembahasan Permasalahan Dan Penerapan Kuhap Pemeriksaan Sidang Pengadilan, Banding, Kasasi, Dan Peninjauan Kembali, Jakarta: Sinar Grafika, (2005), Hlm. 252

${ }^{11}$ Marwan Mas, "Penguatan Argumentasi Fakta-Fakta Persidangan (Marwan Mas)," Jurnal Yudisial, vol. 5, November 23, 2012, https://jurnal.komisiyudisial.go.id/index.php/jy/article/view/125.hlm. 290.

${ }^{12}$ M Erham Amin Et Al., "Kekuatan Pembuktian Penyidik Kepolisian Selaku Saksi Dalam Persidangan Tindak Pidana Narkotika," Badamai Law Journal, $\quad$ Vol. $\quad 5, \quad$ May $\quad 28, \quad 2020$,
} Https://Ppjp.Ulm.Ac.Id/Journal/Index.Php/Blj/Article/View/8537.hlm. 26. 
Penilaian hakim harus berdasarkan fakta dan keadaan serta alat pembuktian yang diperoleh dari hasil pemeriksaan di sidang Pengadilan. Oleh sebab itu harus ada persesuaian atau saling keterkaitan antara alat bukti yang ada yang menjurus kepada apakah benar telah terjadi suatu tindak pidana. ${ }^{13}$ Dalam hal yang periksa sebagai saksi korban adalah seorang penyandang disabilitas berupa retardasi mental tentunya hal tersebut tidaklah mudah mengingat retardasi mental (Mental Retardation) adalah suatu keadaan perkembangan jiwa yang terhenti atau tidak lengkap, yang terutama ditandai oleh terjadinya kendala keterampilan selama masa perkembangan, sehingga berpengaruh pada tingkat kecerdasan secara menyeluruh misalnya kemampuan koknitif, bahasa, motorik dan social. ${ }^{14}$

Indonesia merupakan salah satu negara dengan populasi penyandang disabilitas yang cukup tinggi. Hal ini berarti bahwa potensi terjadinya pelanggaran terhadap hak-hak kaum disabilitas akan banyak terjadi. ${ }^{15}$ Menurut the American Psychiatric Association retardasi mental adalah Our nation's special education law, the IDEA, defines mental retardation as. . .". . significantly subaverage general intellectual functioning, existing concurrently with deficits in adaptive behavior and manifested during the developmental period, that adversely affects a child's educational performance." Atau dengan kata lain dimana Fungsi intelektual umum secara bermakna berada di bawah normal, Dimulai pada masa perkembangan, yang ditandai dengan buruknya kemampuan belajar dan atau kematangan sosial. ${ }^{16}$ Gejala retardasi mental pada tiap orang dapat berbeda-beda, tergantung tingkat keparahan kondisi yang dialami.

Tindak pidana yang sulit pembuktiannya seperti tindak pidana perkosaan biasanya jarang adanya saksi yang melihat kejadian secara langsung kecuali pelaku dan korban, belum lagi jika pelaku terus berkelit dan tidak mau mengakui perbuatannya, sehingga saksi korban penyandang retardasi mental tersebut merupakan saksi yang paling utama dalam tindak pidana perkosaan. Perlindungan terhadap korban kejahatan yang mengalami penderitaan fisik, mental dan atau kerugiaan ekonomi yang diakibatkan oleh suatu tindak pidana, merupakan perlindungan atas keamanan pribadi untuk terbebas dari ancaman yang berkenaan dengan kesaksian yang akan, sedang atau telah diberikannya dalam proses peradilan serta dalam proses memilih dan menentukan bentuk perlindungan dan dukungan keamanan. ${ }^{17}$ Pada dasarnya pelaku tindak pidana menurut sistem hukum Indonesia dapat dipidana apabila tindak pidana yang dilakukan memenuhi unsur-unsur delik yang telah ditentukan dalam undang-undang. ${ }^{18}$ Dalam perkara perkosaan putusan nomor: 425/Pid.B/2017/PN.Gns saksi korban penyandang disabilitas berupa retardasi mental disumpah oleh hakim dalam memberikan keterangannya di Persidangan. Saksi korban penyandang retardasi mental tentunya tidak dapat memberikan keterangan tentang apa yang dialaminya secara sempurna mengungkapkan kejadian tindak pidana pemerkosaan terhadap dirinya. Jelas kesaksiannya tidak dapat dipertanggungjawabkan secara sempurna. Apakah hal tersebut tidak bertentangan dengan Pasal 171 KUHAP dimana yang boleh diperiksa untuk memberi keterangan tanpa sumpah ialah: b.orang sakit ingatan atau sakit jiwa meskipun kadang-kadang ingatannya baik kembali.

\footnotetext{
${ }^{13}$ Penyandang Disabilitas Adalah Setiap Orang Yang Mengalami Keterbatasan Fisik, Intelektual, Mental, Dan/Atau Sensorik Dalam Jangka Waktu Lama Yang Dalam Berinteraksi Dengan Lingkungan Dapat Mengalami Hambatan Dan Kesulitan Untuk Berpartisipasi Secara Penuh Dan Efektif Dengan Warga Negara Lainnya Berdasarkan Kesamaan Hak (Pasal 1 Ayat (1) Undang-Undang Republik Indonesia Nomor 8 Tahun 2016 Tentang Penyandang Disabilitas).

${ }^{14}$ Sylvia D Elvira Gitayanti Hadisukanto, Buku Ajar Psikiatri, Jakarta: Fakultas Kedokteran, Universitas Indonesia, 2017, Hlm 484

${ }^{15}$ Siti Faridah "View Of Lemahnya Penegakan Hukum Dalam Kasus Kekerasan Terhadap Perempuan Penyandang Disabilitas," Jurnal Lex Scientia, Accessed July 7, 2020, Https://Journal.Unnes.Ac.Id/Sju/Index.Php/Lslr/Article/View/30725/13414.

${ }^{16}$ Ferryal Basbeth, Erwin Kristanto, and Rudy Satriyo, "Tindak Pidana Kesusilaan Pada Retardasi Mental : Kasus Yang Belum Terjangkau Oleh Hukum (Laporan Kasus)," Indonesian Journal of Legal and Forensic Sciences, vol. 1, 2008.hlm.13.

17 andika Legesan, "Korban Kejahatan Sebagai Salah Satu Faktor Terjadinya Tindak Pidana Pemerkosaan," LEX CRIMEN, vol. 1, January 10, 2013, https://ejournal.unsrat.ac.id/index.php/lexcrimen/article/view/899.hlm. 17.

${ }^{18}$ Dian Candra Dewi and Subekti E0012113, "Pertanggungjawaban Pidana Penyandang Disabilitas Mental Sebagai Pelaku Tindak Pidana Pencabulan (Studi Putusan Nomor 50/Pid.Sus/2013/Pn.Ska )," Jurnal Hukum Pidana Dan Penanggulangan Kejahatan, vol. 3 (Mei-Agustus, May 1, 2014), www.who.int/mediacentre/factshet.hlm.180.
} 


\section{B. Pembahasan}

\section{Penilaian Hakim Terhadap Keterangan Saksi korban Penyandang Retardasi Mental Dalam Perkara Perkosaan}

Hakim adalah sosok manusia biasa yang oleh undang-undang diberi kekuasaan untuk mengadili dan memutus suatu perkara yang dihadapinya. Hakim dengan kekuasaan kehakiman, kemandirian dan kebebasannya selalu dijamin. ${ }^{19}$ Di dalam menerima, memeriksa, memutus dan menyelesaikan suatu perkara tindak pidana hakim dapat menggunakan kewenangan serta keyakinannya.

Menurut Moeljatno dalam buku Nikmah Rosidah bahwa tindak pidana adalah perbuatan yang dilarang oleh suatu aturan hukum, larangan mana disertai ancaman (sanksi) yang berupa pidana tertentu, bagi barang siapa yang melanggar aturan tersebut. ${ }^{20}$ Salah satu tindak pidana yang sulit pembuktiannya adalah tindak pidana pemerkosaan, karena biasanya tidak terdapat saksi lain yang melihat adanya tindak pidana selain saksi korban sendiri yang mengalaminya serta terdakwa tidak mau mengakui bahwa perbuatan tersebut telah dilakukannya, atau terdakwa berkelik bahwa perbuatan tersebut dilakukan atas dasar suka sama suka.

Hakim dalam menggunakan kewenangan, kemandirian, dan kebebasannya harus jeli untuk memutuskan bahwa telah terjadi tindak pidana perkosaan dan terdakwa sebagai pelakuya, oleh karena itu hakim harus melihat kepada alat bukti dan barang bukti yang ada, terutama keterangan saksi yang ditempatkan menjadi alat bukti pertama dari lima alat bukti yang sah. ${ }^{21}$ Alat bukti yang dimaksud Pasal 184 KUHAP yaitu:

1. Keterangan saksi yaitu apa yang saksi lihat, dengar, dan alami sendiri. Dalam kasus ini terdapat kesulitan di mana dalam kasus pemerkosaan tidak terdapat saksi lain selain saksi korban.

2. Keterangan ahli yaitu apa yang di berikan oleh seorang ahli, dalam kasus pemerkosaan yang di sebut saksi ahli dalam hal ini adalah seorang dokter yang di tunjuk oleh Pengadilan, yang diminta pengetahuannya untuk membuktikan telah terjadi tindak pidana pemerkosaan yang dituangkan dalam Visum Et Repertum. Selain itu dalam perkara tindak pidana yang saksi korbannya mengalami disabiltas retardasi mental diperlukan adanya ahli kejiwaan yang mendapingi saksi korban.

3. Surat dalam tidak pidana pemerkosaan yaitu berupa hasil pemeriksaan dari seorang dokter yang berupa Visum Et Repertum yang di tuliskan dalam selembar kertas. Selain itu dalam perkara tindak pidana yang saksi korbannya mengalami disabiltas retardasi mental diperlukan adanya surat hasil penelitian dari ahli kejiwaan.

4. Petunjuk yaitu yang diperoleh dari keterangan saksi, keterangan terdakwa yang di kumpulkan dan akhirnya menimbulkan sebuah petunjuk yang dapat menguatkan keyakinan hakim.

5. Keterangan terdakwa yaitu apa yang terdakwa nyatakan di persidangan menyangkut hal tindak pidana pemerkosaan. Keterangan terdakwa bisa juga di gunakan untuk mencari fakta-fakta baru yang belum didapat dari alat bukti yang lain.

Dari alat bukti tersebut hakim akan menilai apakah benar telah terjadi tindak pidana perkosaan atau tidak. Oleh sebab itu harus ada persesuaian atau saling keterkaitan antara alat bukti yang ada. Alat bukti yang utama dalam perkara pidana adalah keterangan saksi, tapi ini bukanlah merupakan alat bukti yang mutlak untuk menjatuhkan terdakwa bersalah atau tidak.

\footnotetext{
${ }^{19}$ Nikmah Rosidah, Budaya Hukum Hakim Anak di Indonesia, Semarang: Pustaka Magister, (2014), hlm. 169

${ }^{20}$ Nikmah Rosidah, Asas-asas Hukum Pidana, Semarang: Pustaka Magister, (2011). hlm. 10

${ }^{21}$ Tiovany A. Kawengian, "Peranan Keterangan Saksi Sebagai Salah Satu Alat Bukti Dalam Proses Pidana Menurut KUHAP," LEX PRIVATUM, vol. 4, April 27, 2016, https://ejournal.unsrat.ac.id/index.php/lexprivatum/article/view/11990.hlm. 36.
} 
Dalam tindak pidana perkosaan jarang ada saksi yang melihat langsung kejadian perkosaan tersebut selain saksi korban yang mengalaminya sendiri, tapi setidaknya untuk memutuskan seorang terdakwa bersalah atau tidak, Hakim sebagai salah satu pejabat kekuasaan kehakiman yang melaksankan proses peradilan tentunya mempunyai tanggung jawab yang besar terhadap lahirnya suatu putusan. ${ }^{22}$ Maka putusan hakim haruslah didasarkan pada 2 (dua) syarat yaitu:

a. Minimal 2 (dua) alat bukti;

b. Dari alat bukti tersebut hakim memperoleh keyakinan bahwa terdakwa bersalah melakukan tindak pidana.

Keterangan saksi yang menjadi korban perkosaan, yang dapat menyatakan bahwa dirinya telah mengalami perkosaan, terdapat alat bukti surat berupa Visum Et Repertum dari rumah sakit yang telah ditunjuk, Visum et repertum adalah salah satu alat bukti yang sah sebagaimana tertulis dalam pasal 184 KUHP. Visum et repertum turut berperan dalam proses pembuktian suatu perkara pidana terhadap kesehatan dan jiwa manusia, dimana $V e R$ menguraikan segala sesuatu tentang hasil pemeriksaan medik yang tertuang di dalam bagian pemberitaan, yang karenanya dapat dianggap sebagai pengganti barang bukti. ${ }^{23}$ Dalam hasil pemeriksaan Visum Et Repertum dijelaskan kekerasan yang dialami saksi korban akibat perkosaan. Selain itu barang bukti yang terdapat dalam kasus perkosaan adalah seperti celana dalam, baju milik korban dan terdakwa, serta bisa juga benda lain yang digunakan untuk melakukan tindak pidana tersebut. Karena barang-barang bukti tersebut telah dibenarkan oleh keterangan saksi maka barang bukti tersebut akan mempunyai nilai sebagai alat bukti petunjuk yang dipakai oleh hakim, sehingga alat-alat bukti yang ada dapat memberikan keyakinan bagi hakim. Dengan begitu syarat pembuktian seperti yang diharuskan di dalam KUHAP telah terpenuhi yaitu adanya minimal 2 (dua) alat bukti yang sah dan ada keyakinan hakim untuk memutus perkara tersebut.

Keterangan saksi korban penyandang retardasi mental untuk dapat dijadikan sebagai alat bukti keterangan saksi dimana keterangan saksi digunakan sebagai acuan untuk mencari fakta mengenai kasus yang dialami oleh korban, sedangkan keterangan saksi korban penyandang retardasi mental dianggap tidak kuat seperti keterangan saksi orang normal pada umumnya karena penyandang retardasi mental tidak dapat memberikan keterangan tentang apa yang dilihat, didengar dan dialaminya secara sempurna mengungkapkan kejadian tindak pidana pemerkosaan terhadap dirinya. Jelas kesaksiannya dalam hal ini tidak dapat dipertanggungjawabkan secara sempurna. Menurut Pasal 185 ayat (6) KUHAP, bahwa dalam menilai kebenaran keterangan seorang saksi, hakim harus bersungguh-sungguh memperhatikan $: 24$

a. Persesuaian antara keterangan saksi;

b. Persesuaian keterangan saksi dengan alat bukti lain;

c. Alasan saksi memberikan keterangan tertentu

Bertitik tolak untuk mengambil suatu kesimpulan umum dalam hal ini ialah Pasal 185 ayat (7) KUHAP dengan tanpa mengurangi ketentuan lain yang diatur dalam Pasal 161 ayat (2) KUHAP, maupun Pasal 169 ayat (2) KUHAP dan penjelasan Pasal 171 KUHAP, secara umum dapat disimpulkan sebagai berikut:

\footnotetext{
22 “Asas Kepastian Hukum, Keadilan Dan Kemanfaatan Dalam Kaitannya Dengan Putusan Kepailitan Pengadilan Niaga Wijayanta Jurnal Dinamika Hukum," Accessed July 7, 2020,Http://Dinamikahukum.Fh.Unsoed.Ac.Id/Index.Php/Jdh/Article/View/291/285.Hlm. 217.

23 Dedi Afandi, "Visum et Repertum Pada Korban Hidup," JIK (Jurnal Ilmu Kedokteran), vol. 3, July 14, 2017, https://jik.ejournal.unri.ac.id/index.php/JIK/article/view/3757.hlm. 80.

${ }^{24}$ M. Yahya Harahap, Hukum Acara Perdata, Jakarta: Sinar Grafika, (2012), hlm. 290-291
} 
a) Semua keterangan saksi yang diberikan tanpa sumpah dinilai "bukan merupakan alat bukti yang sah". Walaupun keterangan yang diberikan tanpa sumpah itu saling bersesuaian dengan yang lain, namun sifatnya tetap "bukan merupakan alat bukti";

b) Tidak mempunyai nilai kekuatan pembuktian. Karena sifatnya bukan merupakan alat bukti yang sah, maka dengan sendirinya tidak memiliki nilai kekuatan pembuktian;

c) Akan tetapi "dapat" dipergunakan sebagai "tambahan" alat bukti yang sah. Sekalipun keterangan tanpa sumpah bukan merupakan alat bukti yang sah dan juga tidak memiliki nilai kekuatan pembuktian, pada umumnya keterangan itu menyempurnakan kekuatan pembuktian alat bukti yang sah, yang dapat "menguatkan keyakinan hakim" seperti yang disebutkan dalam Pasal 161 ayat (2) KUHAP dan dapat dipakai "sebagai petunjuk" seperti yang disebutkan dalam penjelasan Pasal 171 KUHAP.

Untuk mempergunakan keterangan tanpa sumpah baik sebagai "tambahan" alat bukti maupun untuk "menguatkan keyakinan hakim" atau sebagai "petunjuk", harus diikuti dengan syarat:

a) Harus lebih dulu ada alat bukti yang sah, misal ada alat bukti keterangan saksi, alat bukti keterangan ahli, alat bukti surat, atau keterangan terdakwa;

b) Alat bukti yang sah telah memenuhi batas minimum pembuktian yakni sekurang-kurangnya dua alat bukti yang sah;

c) Antara keterangan tanpa sumpah itu dengan alat bukti yang sah terdapat saling persesuaian.

Hukum Progresif yang bertumpu pada peraturan dan perilaku (Rules and behavior), menempatkan manusia untuk tidak terbelenggu oleh tali kekang Rules and behavior. Itulah sebabnya ketika terjadi perubahan dalam masyarakat, ketika teks-teks hukum mengalami keterlambatan atas nilai-nilai yang berkembang di masyarakat, penegak hukum tidak boleh hanya membiarkan diri terbelenggu oleh tali kekang rules yang sudah tidak relevan tersebut, tetapi harus melihat keluar (outward), melihat konteks sosial yang sedang berubah tersebut dalam membuat keputusan-keputusan hukum. ${ }^{25}$

Sebagaimana dikemukakan oleh Barda Nawawi Arif dalam buku Nikmah Rosidah bahwa hukum progresif bertumpu pada manusia membawa konseuensi pentingnya kreatifitas. Keratifitas dalam konteks penegakan hukum selain untuk mengatasi ketertinggalan hukum, mengatasi ketimpangan hukum, juga dimaksudkan untuk membuat terobosan-terobosan hukum. Terobosan-terobosan hukum inilah yang dapat diharapkan mewujudkan tujuan melalui bekerjanya hukum, untuk membuat kebahagiaan manusia. Kreatifitas penegak hukum dalam memaknai hukum tidak akan berhenti pada mengejar Undang-undang tetapi menggunakannya secara sadar untuk mencapai tujuan kemanusiaan. Menggunakan hukum secara sadar sebagai sarana pencapaian tujuan kemanusiaan berarti harus peka dan responsif terhadap tuntutan sosial. $^{26}$

Dalam perkara perkosaan Putusan nomor: 425/Pid.B/2017/PN.Gns, dikarenakan tidak ada saksi lain yang melihat terjadinya tindak pidana pemerkosaan atau hanya testimony de auditu ${ }^{27}$, sehingga hakim sebagai penegak hukum melakukan terobosan hukum yaitu dalam pemeriksaan dipersidangan saksi korban penyandang retardasi mental disumpah. Tindakan contra legem ${ }^{28}$ oleh hakim ini didasarkan dengan mempertimbangkan hal tertentu seperti hasil penelitian dari ahli kejiwaan sejauh mana retardasi mental yang dialami oleh saksi korban tersebut dan memandang apakah ahli memiliki cara lain yang bisa dipertanggungjawabkan secara akademis

\footnotetext{
${ }^{25}$ Nikmah Rosidah, Op.Cit, hlm.178

${ }^{26}$ Ibid., hlm. 179

${ }^{27}$ testimony de auditu yaitu kesaksian atau keterangan karena mendengar dari orang lain

${ }^{28}$ contra legem yaitu mengambil putusan yang bertentangan dengan undang-undang yang bersangkutan dengan tujuan untuk mencapai kebenaran dan keadilan
} 
untuk membantu saksi korban yang mengalami retardasi mental agar dapat memberikan keterangan yang tentu saja bisa dipastikan kebenarannya seperti yang dialami oleh saksi korban ini, hal tersebut dapat dilihat dari pertimbangan-pertimbangan hakim yang digunakan dalam menjatukan putusan bersalah kepada terdakwa, walaupun secara konseptual hal ini dapat dianggap sebagai penyimpangan dari Pasal 171 KUHAP, sebagaimana menurut Edi Rifai selaku Dosen Fakultas hukum Universitas lampung bahwa berdasarkan Pasal 171 huruf b KUHAP saksi penyandang retardasi mental dalam memberikan keterangannya tidak dapat disumpah dan hakim dengan kewenanggannya dapat menilai apakah keterangan saksi tersebut dapat digunakan atau tidak, jika dapat di pakai maka hanya sebagai alat bukti petunjuk. Akan tetapi tindakan hakim ini bertujuan untuk mencapai kebenaran dan keadilan.

Hakim dalam menggunakan kewenangan, kemandirian, dan kebebasannya harus jeli untuk mempergunakan alat bukti keterangan saksi penyandang retardasi mental dengan menilai case by case. Hakim tidak terikat atau bebas untuk mempergunakan atau tidak keterangan saksi tersebut sebagai alat bukti, hakim dapat mempergunakannya sebagai alat bukti keterangan saksi, tambahan pembuktian maupun sebagai alat bukti petunjuk apabila terdapat persesuaian dengan alat bukti lain yang sah.

\section{Prinsip Yang Harus Diperhatikan Oleh Hakim Dalam Penilaian Keterangan Saksi Penyandang Retardasi Mental}

Pemeriksaan saksi korban yang mengalami retardasi mental dalam persidangan perkara pidana di Pengadilan pada masa datang dilakukan dengan mengacu pada prinsip-prinsip pengadilan yang fair. Prinsip-prinsip pengadilan yang fair bagi korban pada umumnya dan bagi korban difabel pada khususnya dapat diketahui dari Deklarasi Umum Hak Asasi Manusia, Konvensi Hak-Hak Penyandang Disabilitas, Undang-Undang Hak Asasi Manusia dan UndangUndang Penyandang Disabilitas sebagaimana tersebut di bawah ini:

a. Pasal 7 Deklarasi Umum Hak Asasi Manusia Semua orang sama di depan hukum dan berhak atas perlindungan hukum yang sama tanpa diskriminasi. Semua berhak atas perlindungan yang sama terhadap setiap bentuk diskriminasi yang bertentangan dengan Deklarasi ini, dan terhadap segala hasutan yang mengarah pada diskriminasi semacam ini.

b. Mengenai perlindungan hukum terhadap penyandang disabilitas diatur dalam UndangUndang Nomor Undang-Undang Nomor 19 Tahun 2011 Tentang Pengesahan Convention On The Rights Of Persons With Disabilities (Konvensi Mengenai Hak-Hak Penyandang Disabilitas) dalam Pasal 12 Konvensi Mengenai Hak-Hak Penyandang Disabilitas secara jelas diatur tentang kesetaraan hak dan pengakuan di hadapan hukum kepada penyandang disabilitas dimana pun berada.

c. Pasal 5 Undang-Undang Nomor 39 Tahun 1999 tentang Hak Asasi Manusia dijelaskan bahwa Setiap orang dalam hal ini termasuk penyandang disabilitas diakui sebagai manusia pribadi yang berhak menuntut dan memperoleh perlakuan serta perlindungan yang sama di depan hukum, berhak mendapat bantuan dan perlindungan yang adil dari pengadilan yang objektif dan tidak berpihak dan berhak memperoleh perlakuan dan perlindungan lebih berkenaan dengan kekhususannya.

d. Pasal 31 Undang-Undang Nomor 8 Tahun 2016 tentang Penyandang Disabilitas pendamping harus di izinkan untuk mendampingi penyandang disabilitas, pasal tersebut berbunyi "Penegak hukum dalam melakukan pemeriksaan terhadap anak penyandang disabilitas wajib mengizinkan kepada orang tua atau keluarga anak dan pendamping atau penerjemah untuk mendampingi anak penyandang disabilitas. Dalam hal ini saksi penyandang retardasi mental harus mendapatkan Pendamping ahli kejiwaan berupa dokter spesialis kejiwaan, psikolog atau psikiater yang melakukan penelitian terhadap saksi tersebut, sehingga hasil dari penelitian tersebut dapat digunakan oleh hakim untuk menilai keapsahan keterangan saksi penyandang retardasi mental tersebut. Selain itu pendamping 
tersebut diatas juga digunakan sebagai alat bukti keterangan ahli. Sesuai dengan Pasal 32 Undang-Undang Nomor 8 Tahun 2016 tentang Penyandang Disabilitas apabila penyandang disabilitas dianggap tidak cakap maka hal itu harus dinyatakan berdasarkan penetapan pengadilan negeri.

Hakim dalam menjalankan kewenangannya di persidangan harus memperhatikan prinsip sebagai berikut: ${ }^{29}$

a. Persamaan Kedudukan di Depan Hukum (Equality Before The Law)

Setiap orang mempunyai kedudukan yang sama di depan hukum. Demikian halnya dengan saksi korban difabel juga mempunyai kedudukan yang sama di depan hukum. Setiap warga negara termasuk seorang difabel yang dilanggar haknya maka berhak untuk melakukan penuntutan hukum demikian halnya seseorang yang melanggar hak korban/pelaku harus mendapatkan hukuman yang setimpal dengan perbuatannya melalui proses hukum yang berlaku. Baik korban difabel maupun pelaku harus diperlakukan sama secara prosedur dalam penanganan di pengadilan. Apabila hakim/majelis hakim menetapkan dalam putusan sela sidang pemeriksaan perkara harus dilanjutkan, maka acara persidangan memasuki tahap pembuktian,yaitu pemeriksaan terhadap alat-alat dan barang bukti yang diajukan. ${ }^{30}$ Korban difabel diberikan hak untuk:

1) Menghadiri persidangan;

2) Pemanggilan untuk memberikan keterangan saksi dalam waktu yang layak dan patut;

3) Menyampaikan keterangan sebagai saksi;

4) Tidak dipertemukan dengan terdakwa di dalam persidangan;

5) Diperiksa tanpa hadirnya terdakwa, kemudian hasil pemeriksaan saksi korban difabel disampaikan kepada terdakwa dalam persidangan yang tesendiri;

6) Memberikan mengajukan saksi-saksi;

7) Mengajukan saksi ahli;

8) Mengajukan upaya hukum.

Di dalam persidangan pelaku/terdakwa mempunyai hak untuk:

a) Hadir di dalam pemeriksaan persidangan;

b) Mengakui perbuatannya;

c) Mengingkari perbuatan (hak ingkar);

d) Memberikan pertanyaan kepada saksi yang diajukan di persidanga;

e) Membantah keterangan saksi;

f) Mengajukan saksi yang meringankan (a de charge);

g) Mengajukan upaya hukum.

b. Persidangan Terbuka untuk Umum dan Dilakukan Secara Lisan

Pemeriksaan perkara wajib dilakukan dalam persidangan yang terbuka untuk umum, artinya persidangan dapat dihadiri, dilihat, didengar, dan disaksikan khalayak umum kecuali dalam perkara-perkara tertentu yang harus di lakukan dalam persidangan dilakukan secara tertutup, yaitu persidangan yang tidak boleh dihadiri, dilihat, didengar, dan disaksikan khalayak umum.

Pengertian tertutup untuk umum termasuk juga penyebaran informasi yang terjadi selama persidangan baik oleh hakim, jaksa penuntut umum maupun semua yang diperkenankan hadir yang dilakukan di luar persidangan kecuali undang-undang menentukan lain. Persidangan dilakukan secara lisan dilakukan dengan tujuan untuk memperlancar persidangan,

\footnotetext{
${ }^{29}$ M. Yahya Harahap, Pembahasan Permasalahan dan Penerapan KUHAP, Jakarta: Sinar Grafika, (2012)

${ }^{30}$ Gifard Majore, "Eksepsi Dalam Perkara Pidana Sebagai Hak Terdakwa Dalam Persidangan Pengadilan," Lex Administratum, vol. 4, February 10, 2016, https://ejournal.unsrat.ac.id/index.php/administratum/article/view/11305.hlm. 127.
} 
mempermudah saksi-saksi, terdakwa, maupun siapa saja yang hadir untuk mengikuti jalannya sidang dan tidak menimbulkan kegaduhan atau keributan selama sidang berlangsung.

\section{c. Pengadilan Yang Kompeten, Independen Dan Tidak Memihak Yang Ditetapkan Oleh Hukum}

Pemeriksaan perkara terhadap korban difabel dilakukan oleh jaksa dan hakim yang mempunyai kompetensi dalam pemenuhan hak-hak difabel di dalam persidangan. Dalam setiap pemeriksaan perkara korban difabel disyaratkan untuk dilakukannya pemeriksaan saksi ahli yang memberikan pendapatnya tentang ciri-ciri, katakteristik difabel sebagai bahan untuk mendapatkan kejelasan tentang keterangan yang disampaikan saksi korban difabel dan memberikan keyakinan bagi hakim dalam memberikan putusan sehingga putusannya memberikan keadilan bagi semua pihak terutama keadilan bagi korban difabel.

\section{d. Hak Atas Penterjemah/ Juru Bahasa}

Pasal 178 KUHAP menyebutkan: "Jika terdakwa atau saksi bisu atau tuli serta tidak dapat menulis, hakim ketua sidang mengangkat sebagai penterjemah orang yang pandai bergaul dengan terdakwa atau saksi itu". Hak atas penterjemah dimiliki oleh pelaku dan juga saksi atau saksi korban yang mempunyai jenis disabilitas bisu atau tuli saja padahal masih banyak jenis disabilitas yang lain. Jenis disabilitas lain menjadi tidak terlindungi secara hukum ketika berada dalam posisi pelaku tindak pidana atau saksi.

e. Hak Atas Perlakuan Yang Berperikemanusiaan

Saksi korban bukanlah pelaku pidana maka tidak dapat di perlakukan dengan perlakuan yang sama dengan pelaku. Pelaku saja harus diperlakukan dengan sesuai dengan perikemanusiaan dan menjunjung tinggi harkat dan martabat manusia, tidak disiksa, tidak dipaksa dan tidak ditekan agar pelaku mengakui perbuatannya apalagi saksi korban. Saksi korban harus mendapatkan perlindungan hukum, perlakuan tidak manusiawi terhadap saksi korban hanya akan menjadi saksi korban sebagai korban untuk kedua kalinya setelah menjadi korban perbuatan pidana.

\section{Penutup}

Berdasarkan hasil penelitian dan pembahasan tersebut di atas, maka penulis menarik kesimpulan sebagai berikut:

1. Penilaian hakim terhadap keterangan saksi korban penyandang retardasi mental dalam perkara perkosaan pada dasarnya tidak terikat. Hakim dapat mempergunakan keterangan saksi korban penyandang retardasi mental sebagai alat bukti keterangan saksi dengan mempertimbangkan hasil penelitian dari ahli kejiwaan yang bisa dipertanggungjawabkan secara akademis untuk membantu saksi penyandang retardasi mental agar dapat memberikan keterangan yang tentu saja bisa dipastikan kebenarannya, hakim juga dapat mempergunakannya sebagai tambahan pembuktian maupun sebagai alat bukti petunjuk apabila terdapat persesuaian dengan alat bukti lain yang sah.

2. Prinsip yang harus diperhatikan oleh hakim dalam penilaian keterangan saksi penyandang disabilita retardasi mental dilakukan dengan berdasarkan pada prinsip-prinsip pengadilan yang fair yaitu: persamaan kedudukan di depan hukum, persidangan terbuka untuk umum dan dilakukan secara lisan, pengadilan yang kompeten, independen dan tidak memihak yang ditetapkan oleh hukum, akses terhadap keadilan, akses terhadap informasi, kebebasan dari ekploitasi, kekerasan dan pelecehan, kebebasan dari perlakuan tidak manusiawi dan merendahkan martabat manusia, jaminan prosedur minimal, hak atas mendapat bantuan hukum, hak atas saksi, hak atas penterjemah/jurubahasa, hak atas perlakuan yang berperikemanusiaan. 


\section{Daftar Pustaka}

A. Buku

Harahap, M. Yahya. (2005). Pembahasan Permasalahan dan Penerapan KUHAP Pemeriksaan Sidang Pengadilan, Banding, Kasasi, dan Peninjauan Kembali. Jakarta: Sinar Grafika.

Harahap, M. Yahya. (2012). Hukum Acara Perdata. Jakarta: Sinar Grafika.

Kaligis, Fransiska, W.Edith Humries Pleyte. (2017). Buku Ajar Psikiatri. Fakultas Kedokteran Universitas Indonesia.

Mulyadi, Lilik Mengutip Mardjono Reksodipoetro. (1994). Hak Asasi Manusia Dalam Sistem Peradilan Pidana, Kumpulan Karangan Buku Ketiga, Jakarta: Pusat Pelayanan Keadilan dan Pengabdian Hukum Universitas Indonesia.

Pusat Bahasa Departemen Pendidikan Nasional. (2005). Kamus Besar Bahasa Indonesia. Penerbit Balai Pustaka, Edisi Ketiga, Cetakan Keempat.

Rosidah, Nikmah. (2011). Asas-asas Hukum Pidana. Semarang: Pustaka Magister.

Rosidah, Nikmah. (2014). Budaya Hukum Hakim Anak di Indonesia. Semarang: Pustaka Magister.

Singarimbum, Mastri, Dkk. (1988). Metode Penelitian Survey. Jakarta: LP3ES.

Soedirjo. (1985). Jaksa dan Hakim Dalam Proses Pidana. Jakarta: Akademikia Pressindo

B. Jurnal

Afandi, Dedi. "Visum Et Repertum Pada Korban Hidup." JIK ( Jurnal Ilmu Kedokteran ). Vol. 3, July 14, 2017. Https://Jik.Ejournal.Unri.Ac.Id/Index.Php/JIK/Article/View/3757.

Basbeth, Ferryal, Erwin Kristanto, And Rudy Satriyo. "Tindak Pidana Kesusilaan Pada Retardasi Mental : Kasus Yang Belum Terjangkau Oleh Hukum (Laporan Kasus).” Indonesian Journal Of Legal And Forensic Sciences. Vol. 2008.https://ojs.unud.ac.id/index.php/ijlfs/article/view/3245. https://doi.org/10.24843/10.24843/IJLFS.2008.v01.i01.p09.

Clasina Mutiara Juwita Panjaitan, And Ariyani Putri. "Peran Dari Lembaga Perlindungan Saksi Dan Korban (Lpsk) Dalam Pemerkosaan.” Jurnal Hukum Pidana Dan Penanggulangan Kejahatan. Vol. 2, April 1, 2013. Https://Jurnal.Uns.Ac.Id/Recidive/Article/View/32018.

Dewi, Dian Candra, And Subekti E0012113. "Pertanggungjawaban Pidana Penyandang Disabilitas Mental Sebagai Pelaku Tindak Pidana Pencabulan (Studi Putusan Nomor 50/Pid.Sus/2013/Pn.Ska ).” Jurnal Hukum Pidana Dan Penanggulangan Kejahatan. Vol. 3. Mei-Agustus, May 1, 2014. https://jurnal.uns.ac.id/recidive/article/view/40496/26695.

Erham Amin, M, Puti Damayanti, "Kekuatan Pembuktian Penyidik Kepolisian Selaku Saksi Dalam Persidangan Tindak Pidana Narkotika." Badamai Law Journal. Vol. 5, May 28, 2020. https://ppjp.ulm.ac.id/journal/index.php/blj/article/view/8537/pdf.

Intan, Eka, Putri Lembaga, Konsultan Bantuan, And Hukum Intan. "Begal Anak; Pemenuhan Hak Dan Lembaga Pembinaan Khusus Anak Kelas Ii A Bandar Lampung Fulfillment Of The Rights Of The Child In The Class Ii Special Child Coaching Institution In Bandar Lampung." Cepalo 2, No. 2 (September 12, 2018): 4584.https://jurnal.fh.unila.ac.id/index.php/cepalo/article/view/1764/1480m Https://Doi.Org/10.25041/Cepalo.V2no2.1764.

Kawengian, Tiovany A. "Peranan Keterangan Saksi Sebagai Salah Satu Alat Bukti Dalam Proses Pidana Menurut Kuhap." LEX PRIVATUM. Vol. 4, April 27, 2016. https://ejournal.unsrat.ac.id/index.php/lexprivatum/article/view/11990/11579.

Legesan, Andika. "Korban Kejahatan Sebagai Salah Satu Faktor Terjadinya Tindak Pidana Pemerkosaan." LEX CRIMEN. Vol. 1, January 10, 2013. https://ejournal.unsrat.ac.id/index.php/lexcrimen/article/view/899/714.

Majore, Gifard. "Eksepsi Dalam Perkara Pidana Sebagai Hak Terdakwa Dalam Persidangan Pengadilan." LEX ADMINISTRATUM. Vol. 4, February 10, 2016. https://ejournal.unsrat.ac.id/index.php/administratum/article/view/11305/10894.

Mas, Marwan. "Penguatan Argumentasi Fakta-Fakta Persidangan (Marwan Mas)." Jurnal Yudisial. $\begin{array}{llll}\text { Vol. } & 5, & \text { November } & 23,\end{array}$ 
https://jurnal.komisiyudisial.go.id/index.php/jy/article/view/125/109

http://dx.doi.org/10.29123/jy.v5i3.125.

Putra, And Akbar Saleh. "Tinjauan Yuridis Terhadap Putusan Hakim Yang Mengabaikan Bukti Keterangan Saksi." LEX ET SOCIETATIS. Vol. 1, March 31, 2013. https://ejournal.unsrat.ac.id/index.php/lexetsocietatis/article/view/1313/1064.

View Of Lemahnya Penegakan Hukum Dalam Kasus Kekerasan Terhadap Perempuan Penyandang Disabilitas." Accessed July 2020. Https://Journal.Unnes.Ac.Id/Sju/Index.Php/Lslr/Article/View/30725/13414.

Wijayanta "Asas Kepastian Hukum, Keadilan Dan Kemanfaatan Dalam Kaitannya Dengan Putusan Kepailitan Pengadilan Niaga. Jurnal Dinamika Hukum.” Accessed July 7, 2020. Http://Dinamikahukum.Fh.Unsoed.Ac.Id/Index.Php/JDH/Article/View/291/285.

ZulkarnainRidlwan,"accessedJuly7,2020,https://www.researchgate.net/publication/336371833_S andaran_Moral_Negara_Hukum_Indonesia_di_Era_Disrupsi_Teknologi.

C. Undang-undang

Mahkamah Konstitusi Nomor 65/PUU-VIII/2010 Tanggal 08 Agustus 2011.

Peraturan Pemerintah Nomor 27 Tahun 1983 Jo Peraturan Pemerintah Nomor 58 Tahun 2010 jo Peraturan.

Pemerintah Nomor 92 Tahun 2015 tentang pelaksanaan KUHAP;Putusan Pengadilan Negeri Gunung Sugih nomor: 425/Pid.B/2017/PN.Gns.

Undang - Undang Nomor 8 Tahun 2016 tentang Penyandang Disabilitas;

Undang-Undang Dasar 1945 Hasil Amandemen ke 4.

Undang-Undang Nomor 16 Tahun 2004 tentang Kejaksaan RI.

Undang-Undang Nomor 19 Tahun 2011 tentang Pengesahan Convention on The Rights of Person with Disabilities (Konvensi Hak-Hak Penyandang Disabilitas).

Undang-Undang Nomor 2 Tahun 2002 tentang Kepolisian RI.

Undang-Undang Nomor 39 Tahun 1999 tentang Hak Asasi Manusia.

Undang-Undang Nomor 48 Tahun 2009 tentang Kekuasaan Kehakiman RI.

Undang-Undang Nomor 8 Tahun 1981 tentang Kitab Undang-Undang Hukum Acara Pidana. 
